\title{
Impact of Power Ultrasound on Antihypertensive Activity, Functional Properties, and Thermal Stability of Rapeseed Protein Hydrolysates
}

\author{
Asif Wali, ${ }^{1}$ Haile Ma, ${ }^{1}$ Muhammad Shahnawaz, ${ }^{2}$ Khizar Hayat, $^{3}$ Jian Xiaong, ${ }^{1}$ and Li Jing ${ }^{1}$ \\ ${ }^{1}$ School of Food and Biological Engineering, Jiangsu University, Zhenjiang 212013, China \\ ${ }^{2}$ Department of Agriculture and Food Technology, Karakoram International University, Gilgit 15100, Pakistan \\ ${ }^{3}$ Department of Food Science and Nutrition, College of Food and Agricultural Sciences, King Saud University, \\ P.O. Box 2460, Riyadh 11451, Saudi Arabia
}

Correspondence should be addressed to Haile Ma; mhl@ujs.edu.cn

Received 17 July 2017; Revised 5 October 2017; Accepted 1 November 2017; Published 21 November 2017

Academic Editor: Maria B. P. P. Oliveira

Copyright (C) 2017 Asif Wali et al. This is an open access article distributed under the Creative Commons Attribution License, which permits unrestricted use, distribution, and reproduction in any medium, provided the original work is properly cited.

\begin{abstract}
The effects of power ultrasound pretreatments on the degree of hydrolysis (DH), angiotensin-I-converting enzyme (ACE) inhibitory activity, amino acid composition, surface hydrophobicity, protein solubility, and thermal stability of ACE inhibition of rapeseed protein hydrolysates were evaluated. Ultrasonic pretreatments before enzymolysis in terms of power and exposure time increased the DH and ACE inhibitory activities over the control (without sonication). In this study, maximum DH 22.07\% and ACE inhibitory activity $72.13 \%$ were achieved at $600 \mathrm{~W}$ and $12 \mathrm{~min}$ pretreatment. Compared to the hydrolysates obtained without sonication, the amino acid profile of ultrasound pretreated hydrolysates showed significant changes particularly in the proline content and hydrophobic amino acids with an increased rate of $2.47 \%$ and $6.31 \%$, respectively. Ultrasound pretreatment (600 watts, 12 min) improved functional properties of protein hydrolysates over control by enhancing surface hydrophobicity and solubility index with an increased rate of $130.76 \%$ and $34.22 \%$. Moreover, the stability test showed that the ACE inhibitory activity remains stable against heat treatments. However, extensive heat, prolonged heating time, and alkaline conditions were not in the favor of stability test, while under mild heat and acidic conditions their ACE inhibitory activities were not significantly different from unheated samples.
\end{abstract}

\section{Introduction}

The growing awareness of consumers about the health and sustainability of food poses a great challenge to the food industry to develop healthier, biologically active food and sustainable products [1]. It is known that bioactive peptides derived from food proteins possess various biological activities. The most widely studied activities are angiotensin-Iconverting enzyme (ACE) inhibitory activity and antioxidant activity. Angiotensin-1-converting enzyme (ACE) has great importance in the renin-angiotensin system that plays an important role in the regulation of blood pressure [2]. In the meantime, the food industry produces large amounts of by-products with high protein content such as Isolexx ${ }^{\mathrm{TM}}$ which is a product of TeuTexx Proteins. It has European Food Safety Authority (EFSA) approval under the novel food category. Burcon NutraScience Corp. has made the production of canola protein isolates possible. This process results in two canola protein isolates, one of which being rich in cruciferin (commercially known as Puratein ${ }^{\circledR}$ ) and the other one being rich in napin (commercially known as Supertein $^{\mathrm{TM}}$ ). Both Supertein and Puratein (Burcon NutraScience) have generally recognized as safe (GRAS) status from the US Food and Drug Administration (FDA) for food use [3]. The use of these by-products could be improved by its use as a raw material for the production of functional and bioactive food constituents. Rapeseed protein component has potential properties for human food that remains to be explored. Recently it has been demonstrated that rapeseed protein is of high nutritional importance in human subjects [4]. The rapeseed protein possesses well-balanced amino acid composition $[5,6]$. Rapeseed protein showed interesting and 
unique functional characteristics and could potentially be used in several food matrices [7]. Furthermore, it is suggested that the rapeseed protein is an attractive source of bioactive compounds [5]. According to the existing literature, the enzymatic hydrolysis with proteases (specific or nonspecific) has been a most important process to the production of antioxidative and ACE inhibitory peptides from food proteins [8-10]. The release of bioactive peptides from proteins by traditional enzymatic hydrolysis is influenced by several factors such as enzymatic substrate ratios, $\mathrm{pH}$, hydrolysis time, and hydrolysis temperature [11]. At present, release of bioactive peptides is far enough for use in the food industry. Consequently, the promising approach being researched in the bioactive peptide production is the use of different pretreatments prior to the enzymolysis. In this case, ultrasound in food processing is based on the fact that it can result in significant changes in some chemical, functional, and physical properties of food ingredients that may be of interest as a technological advantage, especially at high power (low frequency, between 20 and $100 \mathrm{kHz}$ ), and it is reported that ultrasound technology is beneficial for being eco-friendly and having promising results, such as reduced hydrolysis time and enlarged determinate bioactivity $[12,13]$. The impact of ultrasound on proteins prior to enzymatic hydrolysis may improve the release of bioactive peptides due to the protein unfolding and enhanced accessibility of enzymes; however, it is influenced by the protein purity and structure [14, 15]. Ultrasonic pretreatment as a nonthermal process for the modification of food ingredients has attracted more attention in the development of new, gentle processes to get better quality and safety of processed foods [16, 17]. Principally sonication acts by producing bubble cavitation in the biological medium. Applications of ultrasound (thermal, mechanical, and cavitation effects) result in physicochemical changes to proteins and peptides owning to the sonochemical reaction, sonolysis of water, formation, and collapse of the cavitational bubble and micro streaming $[18,19]$. Power in the sonication plays an important role in changing materials based on the applied medium characteristics. Therefore, power needs to be optimized in order to achieve maximum results. Simultaneously, it will provide technological and theoretical support for the food industry [20]. Huang et al. [21] reported that the ACE inhibitory activity of garlic powder treated with power ultrasound followed by Alcalase enzymolysis was increased by $170.9 \%$ as compared to the water extract. Li et al. [22] reported that ultrasound pretreatment $(20 \mathrm{kHz}$ probe $)$ at a duty cycle of $2 \mathrm{~s} / 4 \mathrm{~s}$ was concluded as the best option for peanut kernels to increase solubility when hydrolysed with $\alpha$-chymotrypsin and trypsin. In addition, the low-frequency power ultrasound has been applied to improve enzymolysis and ACE inhibitory activities of resulting hydrolysates from various food proteins. For example, milk protein hydrolysates [13] and corn meal protein hydrolysates [23] showed a remarkable increase in the ACE inhibitory activity after ultrasound pretreatment over control samples without sonication. It has been reported that ultrasound pretreatment with probe system can provide better ACE inhibitor activity as compared to an ultrasonic bath system [24]. It was also investigated that high intensity ultrasound increases protein solubility by changing the conformation and structure of the protein in the way the hydrophilic parts of amino acids from the inside are open to the water [25]. They further reported that increase in the solubility was attributed to the temperature rise during sonication with probe-type ultrasound. It was found that using $(20 \mathrm{kHz}$ probe) sonicator improved the surface hydrophobicity and solubility of whey proteins $[26,27]$. The particular biological characteristics of peptides make them potential functional ingredients that can help to improve human health. However, processing conditions in the food industry may affect their bioactivities [28-30]. Limited information is known about the application of high-energy power ultrasound on ACE inhibitory activities and functional properties of rapeseed protein hydrolysates. Therefore, the objectives of this study were to investigate the effect of ultrasound power and pretreatment time on the degree of hydrolysis and ACE inhibitory activities. Furthermore, the amino acid composition and functional properties of ultrasound generated rapeseed protein hydrolysates were also evaluated. Heat treatment, the most common processing step in the food industry, is frequently used for food drying, safety, or stabilization. It is not known whether the ACE inhibitory peptides would maintain their inhibitory activities during the heat treatment of bioactive functional food products in the presence of acid or alkali. Therefore in this study we investigated the processing stability of ACE inhibition rate of rapeseed protein hydrolysates obtained from ultrasonic pretreatment under various conditions. It is hoped that the results of current study may be useful for functional foods production with potent antihypertensive effects.

\section{Material and Methods}

2.1. Material and Reagents. Rapeseed protein was kindly provided by COFCO Eastern Oil \& Grains Industries Co. Ltd. Zhangjiagang, China. Alcalase 2.4 L from Bacillus licheniformis (in solution form with an activity $2.5 \mathrm{AU} / \mathrm{g}$ by Folinphenol method) was purchased from Novozymes Biotech China. Extraction of angiotensin I-converting enzyme was done according to the method [31]. Hipp-His-Leu (HHL) substrate was purchased from Sigma Chemicals Co., Ltd. (St. Louis, MO, USA). All other reagents and chemicals used in this research work were of analytical grade or food grade standards. The distilled water was used to prepare all necessary solutions.

2.2. Ultrasound Pretreatment. An aliquot $(400 \mathrm{~mL})$ of rapeseed protein solutions with a final concentration of $20 \mathrm{gL}^{-1}$ was prepared. The solutions were incubated and stirred continuously using magnetic stirrer for $30 \mathrm{~min}$ in a thermostat water bath at $40^{\circ} \mathrm{C}$ to ensure complete dissolution and then subjected to cool to room temperature. After that, the solutions were given treatment using probe-type sonicator (Figure 1) (GA98-IID, Shanghai Biotechnology Co., Wuxi, China) at $20 \mathrm{kHz}$ with a $1.5 \mathrm{~cm}$ flat tip probe (diameter of $2 \mathrm{~cm}$ ) which was immersed into the rapeseed protein solution for different irradiation time $(3,6,9,12,15$, and $18 \mathrm{~min})$ and at different powers $(200,400,600,800,1000$, and 1200 watts). The maximum output power of the equipment was 1800 watts 


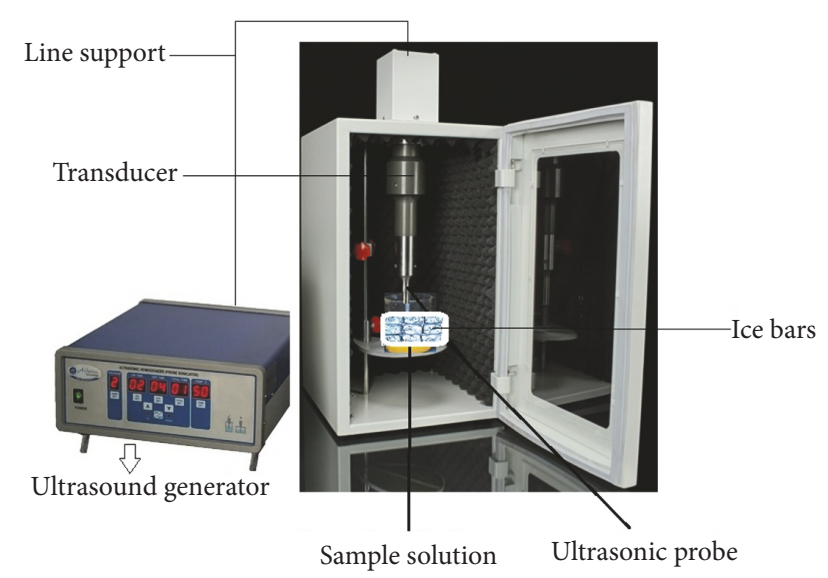

FIGURE 1: Schematic diagram of high power ultrasound equipment.

(pulse durations of on-time and off-time was $3 \mathrm{~s}$ and $2 \mathrm{~s}$, resp.). Before being subjected to the sonication the rapeseed protein solutions were ice jacketed and the treated solution temperature did not exceed $50^{\circ} \mathrm{C}$.

2.3. Rapeseed Protein Enzymolysis Reaction. The mechanical apparatuses for enzymolysis are, namely, $\mathrm{pH}$-meter (pHS-3C Precision $\mathrm{pH} / \mathrm{mV}$ Meter, LIDA instruments, China) and an impeller agitator (JJ-1, Zhong Da Instruments Co., Jiangsu, China) with an operating speed of $100 \mathrm{rpm} / \mathrm{min}$, Centrifuge (TGL-16, High-Speed Tabletop, China), and Digital Thermostat Water Bath (DK-S26, JingHong Experimental Apparatus Co., Shanghai, China). Rapeseed protein solutions with and without ultrasound pretreatment were preincubated at $50^{\circ} \mathrm{C}$ and their $\mathrm{pH}$ values were adjusted to 9.0 using $1 \mathrm{M} \mathrm{NaOH}$. In order to investigate the effect of ultrasonic time and power on angiotensin-I-converting enzyme inhibitory activity, the enzymolysis conditions were set as follows, substrate concentration $20 \mathrm{gL}^{-1}$, enzyme concentration $3000 \mathrm{Ug}^{-1}$, temperature $50^{\circ} \mathrm{C}$, and enzymolysis $120 \mathrm{~min}$. In the enzymolysis procedure $\mathrm{pH}$ was carefully monitored and kept at $\mathrm{pH} 9.0$ using $1 \mathrm{M} \mathrm{NaOH}$. After 120 min of continued hydrolysis, the reaction was terminated by boiling the mixtures for $10 \mathrm{~min}$ and then centrifuged at $3500 \times \mathrm{g}$ for $15 \mathrm{~min}$ at $20^{\circ} \mathrm{C}$. The supernatant was collected and freeze-dried with a freeze dryer (ALPHA 1-2, Martin Christ Inc., Osterode, Germany) and stored at $4^{\circ} \mathrm{C}$ for the subsequent analysis.

2.4. Determination of Degree of Hydrolysis (DH). DH was calculated using the $\mathrm{pH}$-stat method according to (1) described by [32].

$$
\mathrm{DH}=\frac{B \times N_{b}}{\alpha \times M_{p} \times h_{\mathrm{tot}}} \times 100 \% \quad \alpha=\frac{10^{\mathrm{pH}-\mathrm{pK}}}{1+10^{\mathrm{pH}-\mathrm{pK}}},
$$

where $B$ is the amount of base $(\mathrm{mL})$ consumed to maintain the $\mathrm{pH}, \mathrm{N}$ is the concentration of base $\left(\mathrm{mol} \mathrm{L}^{-1}\right)$, and $\alpha$ is average degree of dissociation of the $\mathrm{NH}_{2}$ groups in rapeseed protein substrate which is 0.99 for Alcalase at a temperature $50^{\circ} \mathrm{C}$ and a pH of 9.0. $M_{p}$ is the mass of hydrolysed protein $(\mathrm{g})$ and $h_{\text {tot }}$ is the total number of peptide bonds in the protein substrate ( $7.8 \mathrm{mmol} \mathrm{g}^{-1}$ rapeseed protein).

2.5. Determination of ACE Inhibitory Activity by HPLC. The determination of ACE inhibitory activity was performed according to the method described by Abdualrahman et al. [33]. In brief, $10 \mu \mathrm{L}$ of protein hydrolysate solutions in $0.1 \mathrm{M}$ borate buffer, containing $0.3 \mathrm{M} \mathrm{NaCl}, \mathrm{pH} 8.3$, and $25 \mu \mathrm{L} \mathrm{ACE}$ solution $(20 \mathrm{mU}$ in $0.1 \mathrm{M}$ borate buffer, containing $0.3 \mathrm{M}$ $\mathrm{NaCl}, \mathrm{pH} 8.3$ ) was placed in a cuvette and incubated at $37^{\circ} \mathrm{C}$ for $10 \mathrm{~min}$. The reaction was initiated by adding Hipp-His-leu (6.5 $\mathrm{mM} \mathrm{HHL}$ in the sodium borate buffer $0.1 \mathrm{M}$, containing $0.3 \mathrm{M} \mathrm{NaCl}, \mathrm{pH} 8.3$ ) and the reaction was conducted at $37^{\circ} \mathrm{C}$ for $30 \mathrm{~min}$. The reaction was terminated using $85 \mu \mathrm{L}$ of $1 \mathrm{M} \mathrm{HCl}$ and the mixture was passed through 0.22 -micron filter. The filtrate was used to determine the liberation of HA (hippuric acid) resulting from ACE inhibitory activity on the substrate. The free HA was separated and quantified by HPLC at $228 \mathrm{~nm}$ with UV-detector. A blank was also prepared by replacing the actual sample with distilled water. The ACE inhibitory activity was calculated from (2) given below.

$$
\text { ACE }(\%)=\frac{\text { HA control }- \text { HA sample }}{\text { HA control }} \times 100,
$$

where HA control is the blank peak area of hippuric acid and HA sample is the hydrolysate peak area of hippuric acid

2.6. Amino Acid Composition. The total amino acid composition of the control and ultrasound pretreated sample of $37 \mathrm{mg}$ was hydrolysed in $10 \mathrm{~mL} 6 \mathrm{M} \mathrm{HCl}$ for $24 \mathrm{~h}$ at $110^{\circ} \mathrm{C}$ under a nitrogen atmosphere. The hydrolysate was cooled, filtered, dried in a vacuum desiccator at $45^{\circ} \mathrm{C}$, and redissolved in citrate buffer $(\mathrm{pH} 2.2)$. The samples were analyzed using Sykam S433D amino acids analyzer (Sykam GmbH System + Komponenten analysis her Messtechnik Gewerbering 15 D86922 Eresing, Germany). The injection volume was set at $0.05 \mathrm{~mL}$ while the wavelength was set in the range between 440 and $570 \mathrm{~nm}$.

2.7. Determination of Surface Hydrophobicity Ho. Surface hydrophobicity of rapeseed protein hydrolysates was as determined with 1-anilino-8-naphthalene-sulfonate (ANS) (Sigma Chemical Co., St. Louis, MO, USA) as described by [34] using a fluorescence probe. Samples of $10 \mathrm{mg} \mathrm{mL}^{-1}$ in $0.01 \mathrm{M}$ and $70 \%$ ethanol at $\mathrm{pH} 7.0$ were centrifuged $10,000 \times \mathrm{g}$ at $4^{\circ} \mathrm{C}$ for $10 \mathrm{~min}$. The protein concentration in the supernatant was determined by Lowry method and each sample was serially diluted with aforementioned solvent to obtain protein concentrations ranging 1.0 to $0.2 \mathrm{mg} \mathrm{mL}^{-1}$. After that, $20 \mu \mathrm{L}$ of $8.0 \mathrm{mM}$ ANS (in $0.01 \mathrm{M}$ phosphate buffer at $\mathrm{pH}$ 7.0) was mixed with the diluted protein solution and kept in the dark place for $15 \mathrm{~min}$. Using Cary Eclipse spectrophotometer (Varian Inc., Palo Alto, USA) the relative fluorescence intensities of each sample were measured at $25^{\circ} \mathrm{C}$ and the excitation wavelength $280 \mathrm{~nm}$ and $350 \mathrm{~nm}$ with scanning speed of $120 \mathrm{~nm} \mathrm{~min}^{-1}$. The surface hydrophobicity (Ho) indexes were calculated using linear regression analysis from the initial slope of fluorescence intensity against protein concentrations $\left(\mathrm{mg} \mathrm{mL}^{-1}\right)$. 


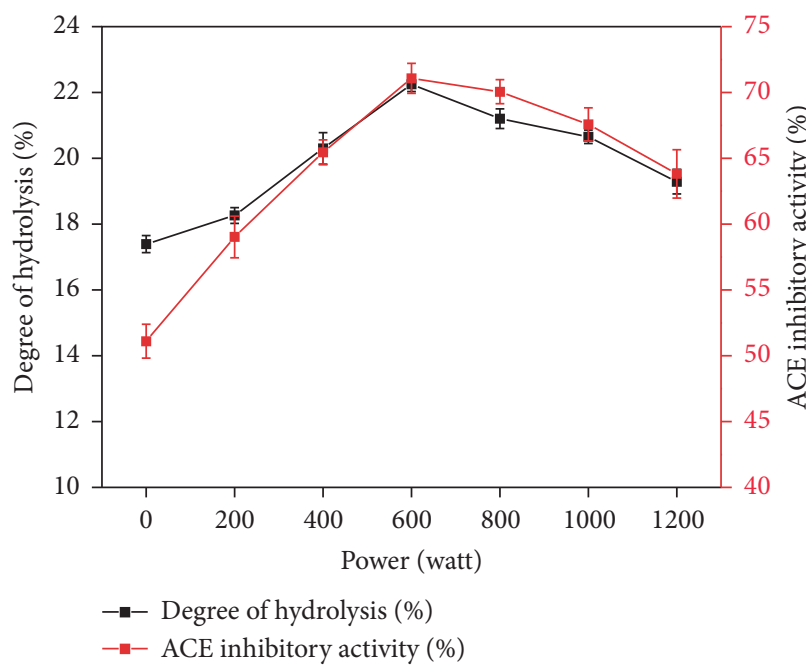

(a)

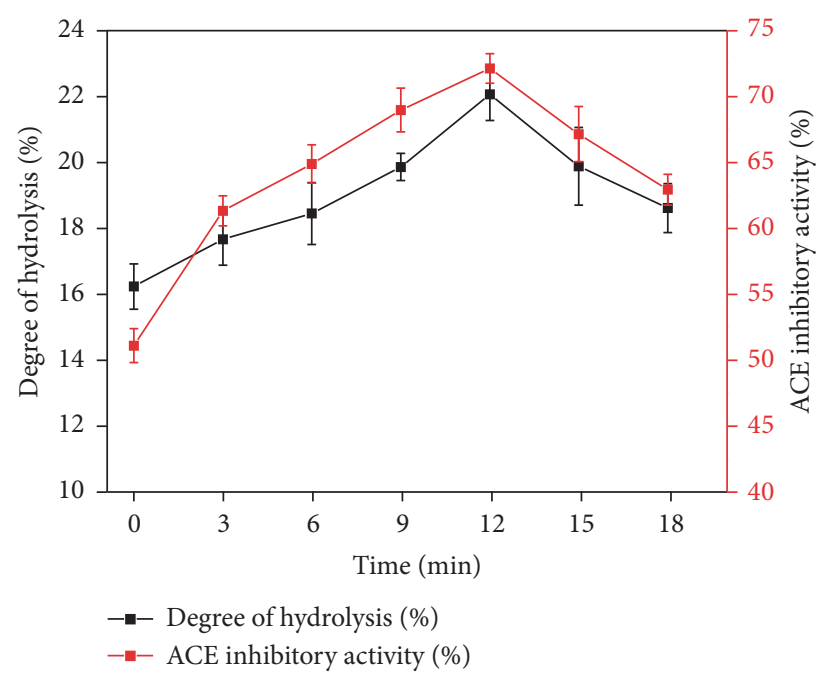

(b)

FIGURE 2: (a) Effect of different powers on DH and ACE inhibitory activity of rapeseed protein hydrolysates. (b) Effect of different pretreatment times on DH and ACE inhibitory activity of rapeseed protein hydrolysates during 120 min of hydrolysis time. Values are presented as mean \pm SD from three replications $(n=3)$.

2.8. Determination of Protein Solubility. The method described by [9] was applied for the protein solubility determination with slight modification. In brief, in $100 \mathrm{~mL}$ distilled water $1 \mathrm{~mL}$ of rapeseed protein hydrolysate was mixed and the $\mathrm{pH}$ of the subsequent mixture was adjusted to the $\mathrm{pH} 7.0$ either $1 \mathrm{M} \mathrm{NaOH}$ or $1 \mathrm{~N} \mathrm{HCl}$, and then the mixture was stirred at room temperature for $30 \mathrm{~min}$ and transferred to a $20 \mathrm{~mL}$ centrifuge tubes and centrifuged at $10,000 \times \mathrm{g}$ at $20^{\circ} \mathrm{C}$ for $15 \mathrm{~min}$. The protein content of both supernatant and sample (native protein) was determined by a Kjeldahl method with the help of Automatic Kjeldahl apparatus (UDK 149. VELP Scientifica Co., Ltd., USmate, Italy). Solubility (\%) of the samples was calculated using the following equation:

$$
\text { Solubility }(\%)=\frac{H p}{R p} \times 100 \text {, }
$$

where $\mathrm{Hp}$ is the protein content in ultrasound pretreated hydrolysed sample and $\mathrm{Rp}$ is the protein content of the rapeseed protein (unhydrolysed and without sonication).

\subsection{Thermal Stability of ACE Inhibitory Activity at Different} Conditions. The thermal stability of ACE inhibitory activity $(66.65 \pm 1.79)$ of ultrasound pretreated rapeseed protein hydrolysate solution of $2 \mathrm{mg} \mathrm{mL}^{-1}$ was investigated under different processing conditions. To examine the effect of $\mathrm{pH}$, hydrolysate solutions were adjusted to $\mathrm{pH}$ values $3,5,7,9$, and 11 using $0.5 \mathrm{M} \mathrm{NaOH}$ or $0.5 \mathrm{M} \mathrm{HCl}$ and incubated for $1 \mathrm{~h}$ at $100^{\circ} \mathrm{C}$. To evaluate the effect of various temperatures $(40,60,80,100$, and 120$)$ on the stability of ACE inhibitory activity, the solutions were adjusted to $\mathrm{pH} 7.0$ and incubated in the thermostat water bath for $1 \mathrm{~h}$. Similarly, to investigate the effect of heating times $(30,60,90$, and 120) the solution was treated at $\mathrm{pH} 7.0$ and temperature $100^{\circ} \mathrm{C}$. Unheated hydrolysate sample obtained from sonication was chosen as reference. All the treated solutions were adjusted to $\mathrm{pH}$ 7.0 and allowed to stay at room temperature before ACE inhibitory assays. In this experiment, each treatment was conducted in triplicate.

2.10. Statistical Analysis. In this study, all experiments were conducted in triplicate, and their mean values were taken from each sample. The statistical software Minitab 16 (Minitab Inc. 1829 Pine Hall Road, 16801) was used in this study. One-way analysis of variance (ANOVA) was conducted to determine the significance at $p<0.05$ of the main effects, using Duncan's multiple range test. Data were expressed as mean $\pm \mathrm{SD}$ (standard deviation). All the graphs were prepared using OriginPro 9.0 (OriginLab Corporation, MA, USA)

\section{Results and Discussion}

3.1. Effect of Ultrasonic Power and Time on Degree of Hydrolysis and ACE Inhibitory Activities. Numerous studies have shown that sonication causes various chemical and biological effects depending on sonication intensity and exposure duration [35]. Figure 2(a) illustrates the values of $\mathrm{DH}$ and ACE inhibitory activities hydrolysates obtained under different power and time followed by enzymatic hydrolysis of $120 \mathrm{~min}$. It can be seen that both DH and ACE inhibitory activities showed a similar pattern; with power and time increased, the DH and ACE inhibitory activities then remarkably decreased. However, the maximum DH and ACE inhibitory activity were achieved at the power of $600 \mathrm{~W}$ and ultrasonic exposure time of $12 \mathrm{~min}$. As compared to the control (without pretreatment followed by enzymolysis) the increase in $\mathrm{DH}$ was $27.95 \%$, while the rate of increase in the ACE inhibitory activity was $39.08 \%$. Furthermore, the effects of ultrasonic 
power on ACE inhibitory activity showed a significant difference between the powers of 0, 200, 400, 600, and $1200 \mathrm{~W}$. Effect of sonication time on DH and ACE inhibitory activity is shown in Figure 2(b).

It was observed that the ultrasonic pretreatment time had a significant effect on the DH. Likewise, increasing the sonication time from 3 to 12 min gave rise to the $\mathrm{DH}$ from 16.24 to $22.07 \%$. These results agree with previous studies where it was seen that sonication prior to enzymolysis increased the $\mathrm{DH}$ and the enzymolysis rate [36-38]. Similarly, the exposure time of sonication greatly increased the ACE inhibitory activity from 51.10 to $72.13 \%$. However, the maximum rate of inhibition appeared at pretreatment time of $12 \mathrm{~min}$. It is reported that the ultrasonic pretreatment of proteins prior to the enzymolysis for short time produced highest ACE inhibitory peptides $[12,39]$. The degree of hydrolysis has a vital role as it greatly affects the hydrolysates functional and their biological activities. Ultrasound could promote series of effects such as thermal, cavitational, and mechanical. Such effects could bring changes to the protein structure by exposing more enzyme sites and by enhancing the protein extensibility [40]. Furthermore, the structural changes induced by sonication could promote enzymolysis efficiency by escalating the combination of the proteolytic enzymes and proteins [37]. The improved enzymolysis was because of the high intensity power ultrasound and sonochemistry effects assisted to disrupt strong solute-matrix interactions, which involved hydrogen bonding, Van de Walls forces, and dipole attractions between the molecules. Furthermore, the exposure of active center caused by power ultrasound would make enzyme combine easily with rapeseed protein and exhibit higher efficient enzymatic hydrolysis. Sonication followed by enzymatic hydrolysis can enhance the surface hydrophobicity and loosen the rapeseed protein tissues, which promotes the release of hydrophobic amino acids. Hydrophobic nature of amino acids plays an important role in the ACE inhibitory activities [41]. This might also be the reason that this phenomenon has led to an increase of both $\mathrm{DH}$ and ACE inhibitory activity of rapeseed protein hydrolysates. Furthermore, this study also discovered that $\mathrm{DH}$ of the rapeseed protein has a positive relation with ACE inhibitory activity. It is suggested that ultrasound pretreatment and controlled enzymolysis might be a promising technique to enhance the $\mathrm{DH}$ and functional characteristics of protein hydrolysates, and this change will undoubtedly further lead to the release of ACE inhibitory peptides. It has been reported that extensive hydrolysis has been associated with improved ACE inhibitory activity [42].

\subsection{Effect of Ultrasound Pretreatment on Amino Acid Com-} position of Rapeseed Protein Hydrolysates. The amino acid composition of hydrolysates of the same protein in native or denatured forms may vary due to changes at the structural level. In general, denaturation of the proteins deploys them thus increasing their susceptibility to enzymatic proteolysis and may lead to different peptide profiles [43-45]. In order to further clarify the ultrasonic pretreatment mechanism on the release of ACE inhibitors from rapeseed protein, the
TABLE 1: Amino acid composition of rapeseed protein hydrolysates with and without ultrasound pretreatment.

\begin{tabular}{|c|c|c|c|}
\hline \multirow{2}{*}{ Amino acids } & \multicolumn{2}{|c|}{ Content $\mathrm{mg} \mathrm{mg}^{-1}$} & \multirow{2}{*}{ Percent increase \% } \\
\hline & $\mathrm{RPH}$ & US-RPH & \\
\hline Asp D (aspartic acid) & 8.09 & 8.12 & \\
\hline Thr T (threonine) & 4.96 & 4.63 & \\
\hline Ser S (serine) & 4.96 & 4.85 & \\
\hline Glu E (glutamic acid) & 21.49 & 20.86 & \\
\hline Gly G (glycine) & 5.89 & 5.80 & \\
\hline Ala A (alanine) & 5.12 & 5.30 & \\
\hline Cys C (cysteine) & 1.89 & 1.57 & \\
\hline Val V (valine) & 5.43 & 5.63 & \\
\hline Met M (methionine) & 1.19 & 1.60 & \\
\hline Ile I (isoleucine) & 4.07 & 4.53 & \\
\hline Leu L (leucine) & 7.92 & 8.53 & \\
\hline Tyr Y (tyrosine) & 2.85 & 3.45 & \\
\hline Phe F (phenylalanine) & 4.42 & 4.59 & \\
\hline His $\mathrm{H}$ (histidine) & 4.05 & 3.84 & \\
\hline Lys K (lysine) & 5.63 & 4.97 & \\
\hline Arg R (arginine) & 6.37 & 5.94 & \\
\hline Trp W (tryptophan) & ND & ND & \\
\hline Pro P (proline) & 5.67 & 5.81 & 2.47 \\
\hline Asn N (asparagine) & ND & ND & \\
\hline Glu Q (glutamine) & ND & ND & \\
\hline HAAs & 38.56 & 40.99 & 6.31 \\
\hline SCAAs & 3.08 & 3.16 & 2.59 \\
\hline EAAs & 54.16 & 55.38 & 2.26 \\
\hline
\end{tabular}

RPH (rapeseed protein hydrolysates without ultrasound pretreatment), USRPH (rapeseed protein hydrolysate with ultrasound pretreatment), HAAs (hydrophobic amino acids: cysteine, valine, isoleucine, leucine, alanine, tyrosine, phenylalanine, methionine, and proline), EAAs (essential amino acids: threonine, tyrosine, cysteine, lysine, histidine, arginine, valine, leucine, isoleucine, and methionine), and SCAAs (sulphur-containing amino acids: cysteine and methionine). Ultrasound pretreatment conditions $600 \mathrm{~W}$ and pretreatment $12 \mathrm{~min}$.

hydrolysed amino acid composition has been examined with sonication and without sonication as illustrated in Table 1.

As shown in Table 1, rapeseed hydrolysate that had been subjected to ultrasonic pretreatment showed a higher relative concentration of hydrophobic amino acids (6.31\%), with a particularly notable increase $(2.47 \%$ ) in proline (Pro) content, as compared to the control. These results are in agreement with previous studies conducted on ultrasound pretreatment [40, 45, 46]. Enzymatic hydrolysis with Alcalase can lead to the production of a rich content of hydrophobic amino acids in the C-terminus since the Alcalase prefers to cleave residues of hydrophobic amino acids at C-terminal (Ile, Val, Ala, Leu, Pro, Phe, Met, and Trp) [47]. Therefore, it is evident that enzymolysis of rapeseed protein with ultrasound pretreatment has a tendency to produce more peptides with a C-terminal hydrophobic amino acid residue than does enzymolysis of rapeseed protein without ultrasound pretreatment. Subsequently, ultrasound pretreatment causes more hydrophobic groups and regions inside the molecules to be exposed outside. According to the structure-activity 


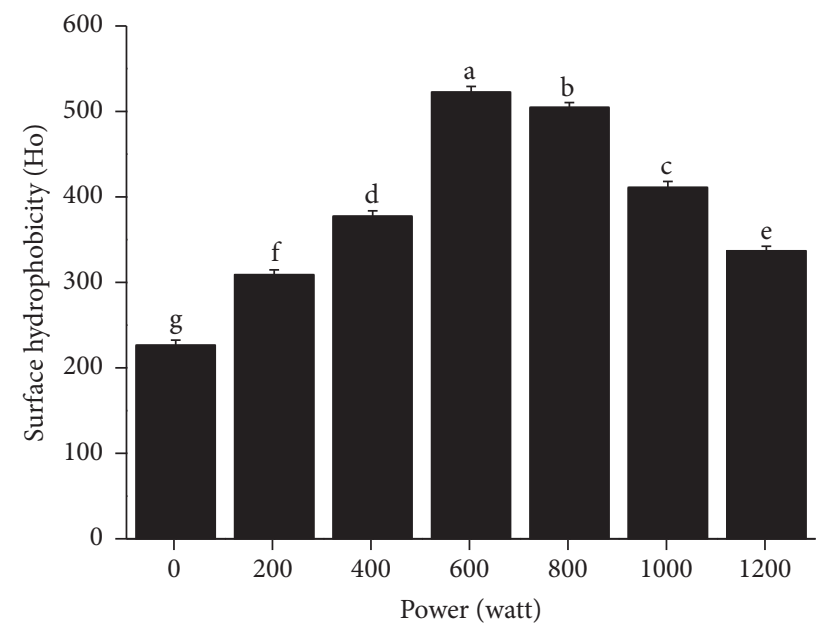

FIGURE 3: Effect of ultrasonic power on the surface hydrophobicity (Ho) of rapeseed protein hydrolysates. Pretreatment time $12 \mathrm{~min}$ and hydrolysis time $120 \mathrm{~min}$. 0 represents hydrolysate without sonication. Different lowercase letters denote statistically different values $(p<0.05)$.

characteristics of the ACE inhibitory peptides, preferred ACE inhibitors are those that contain hydrophobic amino acids on the C-terminal [48]. The increased hydrophobic amino acid content of ultrasound pretreated rapeseed protein hydrolysates are related to the high ACE inhibitory activity. It is reported that the casein hydrolysate of Aspergillus oryzae, expressed dominant role of antihypertensive effects in spontaneously hypertensive rats, mainly contains short peptides X-Pro sequences and X-Pro-Pro. Pro is beneficial for the stability of the ACE inhibitory peptides [49]. ACE inhibitory peptides having Pro residue, especially the Cterminus, are generally resistant to degradation by digestive enzymes [48]. Therefore, ultrasound pretreatment followed by enzymolysis with Alcalase is favorable to enhance the ACE inhibitory activity of rapeseed protein hydrolysates.

3.3. Effect of Ultrasound Power on Surface Hydrophobicity (Ho) of Rapeseed Protein Hydrolysates. The surface hydrophobicity (Ho) shows the number of hydrophobic groups exposed on the surface of protein molecules. ANS fluorescent probe method is a commonly used method to evaluate the hydrophobicity of protein surface and conformational changes of proteins. The hydrophobic interactions are crucial for the functional properties of proteins. Because of their macromolecular structure, surface hydrophobicity greatly influences the functionality of proteins compared to the total hydrophobicity [26]. The fluorescence intensity of ANS and protein is positively correlated with the surface hydrophobicity of protein $[34,50]$. As can be seen from Figure 3, the surface hydrophobicity of the protein samples pretreated by ultrasound was significantly higher than that of the control group (without sonication), ultrasound pretreatment significantly $(p<0.05)$ improved the surface hydrophobicity of rapeseed protein hydrolysates, and these results are consistent with the results reported in the literature $[24,51,52]$. The increased hydrophobicity of the protein surface indicates that the protein molecules are stretched under the cavitation of the ultrasound, thus exposing the hydrophobic groups located inside the protein molecule. The results showed that the hydrophobic groups in the rapeseed protein molecules were exposed under the ultrasonic cavitation. Thus, its surface hydrophobicity increase greatly, which shows that, after the release of more hydrophobic sites, ultrasonic treatment was indeed one of the important reasons for improvement of ACE hydrolysate inhibition rate. Ultrasonic pretreatment of $20 \mathrm{kHz}$ can significantly improve the surface hydrophobicity from 200 to $600 \mathrm{~W}$. For different ultrasonic powers 200-1200 W, the greatest effect was observed in the sample of $600 \mathrm{~W}$ followed by the $800 \mathrm{~W}$ pretreated samples. With the extension of the ultrasonic power, the protein surface hydrophobicity fluctuated after an upward-downward trend, which is consistent with the changes in protein hydrolysates ACE inhibition rate trend. The declining trend in the surface hydrophobicity might be attributed to the formation of protein aggregates and denaturation at high ultrasonication, which may protect hydrophobic sites from exposure in the proteins and also lead to increasing the extent of bonding; thus, the surface hydrophobicity decreased [26, 53]. Ultrasonic pretreatment makes partial denaturation of proteins, and partial denaturation of proteins will expose some of the hydrophobic peptides buried in the natural form to effectively alter the surface properties of the protein and cause an increase in hydrophobicity and this change is likely to be the main reason for the aggregation of proteins during refolding $[27,54,55]$. The simultaneous exposure of the hydrophobic peptide is beneficial for the enhancement of ACE inhibitory activity of hydrolysates.

\subsection{Effect of Ultrasound Pretreatment on Solubility of Rapeseed} Protein Hydrolysates. Solubility is the most practical method of determining protein denaturation and aggregation and therefore is a good protein functional index. The poor proteins solubility is usually associated with reduced functionalities and therefore sufficient solubility of hydrolysates is an important determinant of functionality. Solubility is an important parameter to measure protein aggregation and denaturation and it is, thus, a reliable index of functionality. The results showed that both traditional and ultrasound pretreated enzymolysis significantly $(p<0.05)$ improved solubility. The solubility of rapeseed protein increased significantly $(p<0.05)$ after enzymolysis with ultrasonic power $600 \mathrm{~W}$ and time $12 \mathrm{~min}$. The data was shown in Figure 4.

It can be seen from the figure that the protein solubility increased from $45.16 \%$ to $73.98 \%$ in the ultrasound pretreated rapeseed protein hydrolysates (US-RPH) at $\mathrm{pH}$ 7.0. Meanwhile, enzymolysis alone had also a great impact on solubility index; evidence from Figure 3 shows a significant increase over the native rapeseed protein. This may be due to the fact that the proteins were present in aggregates form in the natural state; the cavitational effects may disrupt the hydrophobic interaction and hydrogen bonds which were responsible for the intermolecular association of protein aggregates. It is reported that increasing the $\mathrm{DH}$ increases the amount of 


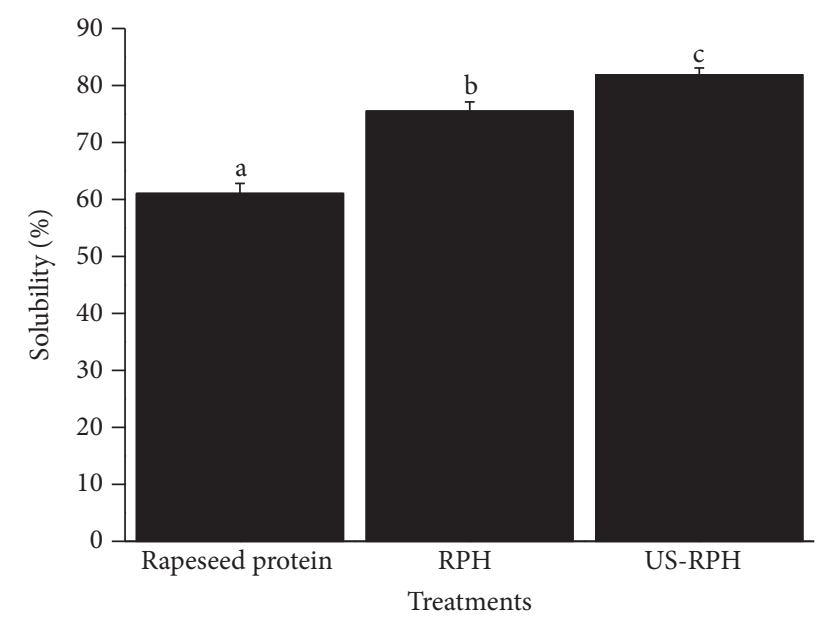

Solubility

Figure 4: Effect of enzymolysis with and without sonication on protein solubility of rapeseed protein. Pretreatment conditions were ultrasound power $600 \mathrm{~W}$ and pretreatment time $12 \mathrm{~min}$. Hydrolysis time $120 \mathrm{~min}$. RPH (protein hydrolysate without pretreatment) and US-RPH (protein hydrolysate with pretreatment). Different lowercase letters denote statistically different values $(p<0.05)$.

potentially ionizable $\mathrm{NH}_{4}^{+}$and $\mathrm{COO}^{-}$groups which can consequently improve the solubility [56]. The increase in the solubility might be attributed to conformational and structural changes so that hydrophilic amino acids residues are reoriented towards the water. Generally, higher solubility implies better emulsion, gelation, and foaming properties [57]. It has been reported that sonication could favor the enlargement of soluble protein aggregates from insoluble precipitates [58]. Higher solubility after sonication is also reported some other researchers $[9,27,53,54,59]$. It can be concluded that rapeseed protein pretreatment by ultrasound is an attractive approach improvement of functional characteristics. It has been reported that the release of smaller polypeptides units and reduced secondary structure contents are liable for the increased solubility of hydrolysates over native intact protein $[60,61]$

3.5. Thermal Stability of Rapeseed Protein Hydrolysate ACE Inhibitory Activity. The rapeseed protein hydrolysates obtained from ultrasound pretreatment can be delivered in the form of incorporated or functional ingredients into other processed foods. In this state, it is required to consider the stability of ultrasound generated ACE inhibitory activity of hydrolysates among the typical $\mathrm{pH}$ levels, temperature, and heating times. These processing conditions are commonly practiced for processed food in the food industry. It was meaningful to determine the stability of ACE inhibitory activity when subjected to various sonication treatments. The $\mathrm{pH}$ changes of hydrolysates were conducted at $100^{\circ} \mathrm{C}$ for $60 \mathrm{~min}$ of heating time as shown in Figure 5(a). It can be seen that there were no significant changes between the ACE inhibitory activity of heated hydrolysates and the control group in the $\mathrm{pH}$ range of 3 to $7(p>0.05)$. These results indicate the $\mathrm{pH}$-stability of bioactive hydrolysates in both acidic and alkaline conditions of the food processing. Stability of ACE inhibition in the various ranges of $\mathrm{pH}$ was also reported in the literature; it was found that algae protein hydrolysates completely retained its activity in the $\mathrm{pH}$ range of 2 to 10 [62]. Nevertheless, ACE inhibition rate of the rapeseed protein hydrolysates showed a remarkable decrease when $\mathrm{pH}$ increased from 9 to 11. Furthermore, compared to the control group the hydrolysates lost their ACE inhibitory activity by $17.35 \%$ when the $\mathrm{pH}$ was 11 indicating that strong alkaline conditions could noticeably reduce the ACE inhibitory activity. The reduction in the rate of inhibition might be attributed to the hydrolysis or degradation of the bioactive peptide into immobile fragments under extreme alkaline heating. It was reported that higher $\mathrm{pH}$ values are influential for the deamination reaction, which can alter the conformation and structure of the peptides, thus the loss of bioactivity [63].

Heat treatments play an important role in the food processing. It greatly affects protein aggregation and denaturation during temperature varying from 60 to $90^{\circ} \mathrm{C}[64,65]$. Figure 5(b) illustrates the effect of different combinations of temperature $\left(40\right.$ to $120^{\circ} \mathrm{C}$ ) on ACE inhibitory activity of rapeseed protein hydrolysates at $\mathrm{pH} 7.0$ and time $1 \mathrm{~h}$. The result showed that there were no significant differences in the ACE inhibitory activities of rapeseed protein hydrolysates of heated and unheated treatments within the processing temperature ranging between 40 and $100^{\circ} \mathrm{C}(p>0.05)$. However, when the hydrolysates were heated above $100^{\circ} \mathrm{C}$, the ACE inhibition rate significantly decreased. When compared to that of the control group, the ACE inhibitory activity decreased by $20.50 \%$ at $120^{\circ} \mathrm{C}$. Extreme heating or sterilization may result in the decrease of ACE inhibitory activity due to loss of some available peptides $[66,67]$. Furthermore, the $\mathrm{C}$-terminal residues strongly influence the ACE inhibition and it is also enlarged by the presence of the +ve charge lysine and arginine as C-terminal residue. Thus, severe heating could bring changes to the C-terminal sequence; therefore, the ACE inhibitory activities of rapeseed protein hydrolysates were significantly affected [68].

The thermal processing may also affect the biological activity of rapeseed protein hydrolysates. The effects of various heating times ( 30 to $120 \mathrm{~min}$ ) at $\mathrm{pH} 7.0$ and temperature $100^{\circ} \mathrm{C}$ on ACE inhibitory activity were shown in Figure 5(c). The results showed no statistical difference between the thermally processed and the control group $(p>0.05)$ in the range of 30 to $90 \mathrm{~min}$ of heating. However, compared to the control a negligible decrease by $6.17 \%$ was observed between 30 and $60 \mathrm{~min}$ of heating. It can be concluded that the hydrolysates derived from sonication could stabilize the ACE inhibitory activity up to $90 \mathrm{~min}$. However, a further increase in the heating time decreased the ACE inhibitory activity. It has been reported in the literature with different heating time showing similar activities up to threshold value and then declining $[66,69]$. In general, rapeseed protein hydrolysates proved to be a good source of ACE inhibitory peptides with strong stability against various processing conditions. 


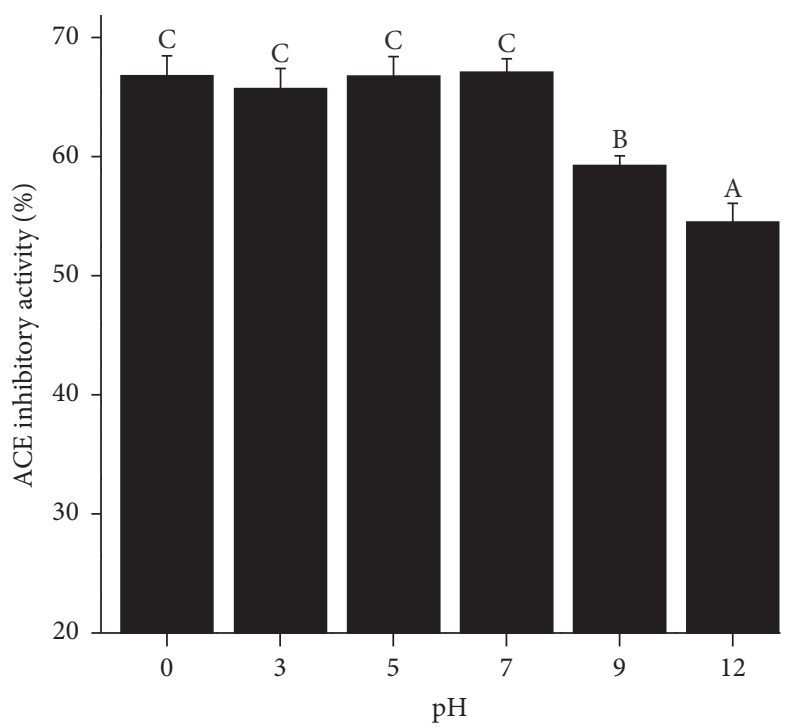

(a)

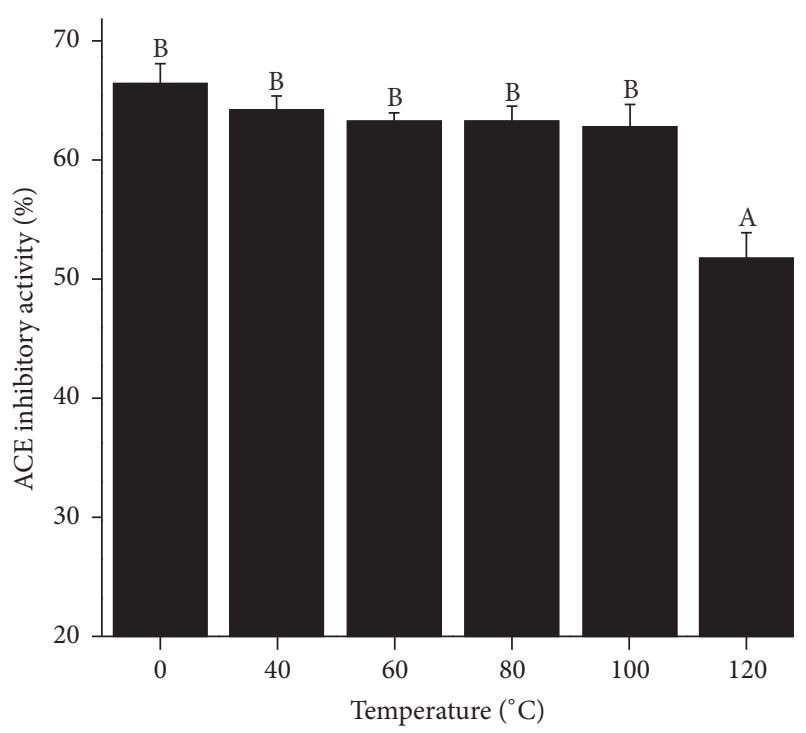

(b)

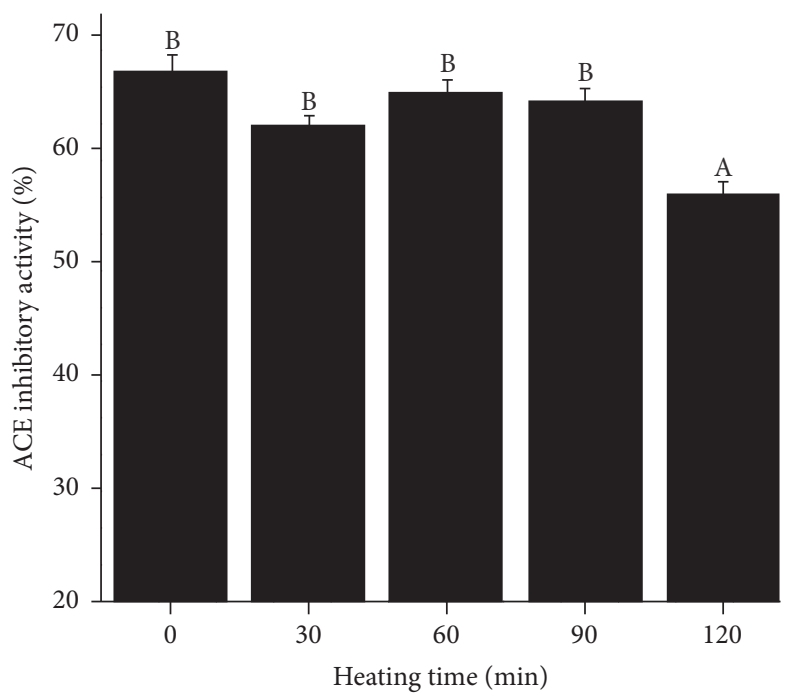

(c)

FIGURE 5: Changes in the ACE inhibitory activity of ultrasound pretreated rapeseed protein hydrolysates (a) at various $\mathrm{pH}$ levels 3 to 11 for $60 \mathrm{~min}$ heating time at $100^{\circ} \mathrm{C}$ while 0 denotes control group, (b) at various temperatures 40 to $120^{\circ} \mathrm{C}$ at $\mathrm{pH} 7.0$ for $60 \mathrm{~min}$ heating, and (c) for different heating times 30 to $120 \mathrm{~min}$ at $\mathrm{pH} 7.0$ and $100^{\circ} \mathrm{C}$. Data are shown as mean $\pm \mathrm{SD}$. Different uppercase letters are significantly different at $p>0.05$.

3.6. Conclusion. The results of the current study indicate that ultrasound pretreatment with power 600 watts and pretreatment time 12 min remained satisfactory to obtain maximum ACE inhibitory activity. Compared to conventional enzymolysis, high-energy power ultrasound pretreatment of rapeseed protein significantly increased the DH and ACE inhibitory activity, surface hydrophobicity, protein solubility, and HAAs amino acids. Specifically, sonication power and exposure times had greatly impacted the DH and ACE inhibitory activities of rapeseed protein hydrolysates. From this study, we can conclude that thermal, mechanical, and chemical effects of power ultrasound pretreatments with 600-watt power and $12 \mathrm{~min}$ pretreatment time enhanced the enzymatic hydrolysis and ACE inhibitory activity and improved the functional properties of rapeseed protein hydrolysates. The mechanism of the efficiency of enzymolysis after sonication was probably due to the increased affinity between enzyme (Alcalase) and substrate (rapeseed protein). However, the relationship between the ultrasound pretreatment and application of Alcalase assisted enzymolysis induced changes in amino acid profile as well as in the functional properties of rapeseed protein hydrolysates which seemed to be clear. The results further showed that sonication with optimum power and exposure time is an effective process to increase the enzymolysis efficiency and ACE inhibitory activities in hydrolysates of rapeseed protein. The thermal stability of 
bioactivity of hydrolysates after various $\mathrm{pH}$, heating, and temperature was a prerequisite in the production of functional foods. It is suggested that ultrasound pretreatment before initiation of enzymatic hydrolysis presents its novelty in enhancing the bioactivity and functional properties of rapeseed proteins which could be incorporated effortlessly into an industrial setup.

\section{Conflicts of Interest}

All authors declare no conflicts of interest.

\section{Authors' Contributions}

All the authors listed in this manuscript contributed equally and read and approved the manuscript.

\section{Acknowledgments}

The authors wish to express their deep gratitude and appreciation for the support obtained from the National High Technology Research and Development Program 863 (no. 2013AA100203) and the Jiangsu Provincial Major Project on Natural Science for Universities (no. 12KJA550001).

\section{References}

[1] D. M. Rivera Rodríguez, M. M. Macedo Fernandes, and T. Tzanov, "Rapeseed protein-derived bioactive peptides: production, processing and potential health benefits," NOVA Publishers, 2016.

[2] S. Rao, J. Sun, Y. Liu, H. Zeng, Y. Su, and Y. Yang, "ACE inhibitory peptides and antioxidant peptides derived from in vitro digestion hydrolysate of hen egg white lysozyme," Food Chemistry, vol. 135, no. 3, pp. 1245-1252, 2012.

[3] L. Campbell, C. B. Rempel, and J. P. D. Wanasundara, "Canola/ rapeseed protein: Future opportunities and directionsworkshop proceedings of IRC 2015," Plants, vol. 5, no. 2, pp. 281-284, 2016.

[4] C. Bos, G. Airinei, F. Mariotti et al., "The poor digestibility of rapeseed protein is balanced by its very high metabolic utilization in humans," Journal of Nutrition, vol. 137, no. 3, pp. 594-600, 2007.

[5] S. Mäkinen, T. Johannson, E. Vegarud Gerd, J. M. Pihlava, and A. Pihlanto, "Angiotensin I-converting enzyme inhibitory and antioxidant properties of rapeseed hydrolysates," Journal of Functional Foods, vol. 4, no. 3, pp. 575-583, 2012.

[6] G. Mariscal-Landín, T. C. Reis de Souza, J. E. Parra S., A. Aguilera B., and B. Mar B., "Ileal digestibility of protein and amino acids from canola meal in weaned piglets and growing pigs," Livestock Science, vol. 116, no. 1-3, pp. 53-62, 2008.

[7] R. Y. Khattab and S. D. Arntfield, "Functional properties of raw and processed canola meal," LWT-Food Science and Technology, vol. 42, no. 6, pp. 1119-1124, 2009.

[8] A. Pihlanto-Leppälä, "Bioactive peptides derived from bovine whey proteins: opioid and ace-inhibitory peptides," Trends in Food Science \& Technology, vol. 11, no. 9-10, pp. 347-356, 2000.
[9] H. Uluko, S. Zhang, L. Liu et al., "Effects of microwave and ultrasound pretreatments on enzymolysis of milk protein concentrate with different enzymes," International Journal of Food Science \& Technology, vol. 48, no. 11, pp. 2250-2257, 2013.

[10] J. Wu, R. E. Aluko, and S. Nakai, "Structural requirements of angiotensin I-converting enzyme inhibitory peptides: Quantitative structure-activity relationship study of $\mathrm{Di}$ - and tripeptides," Journal of Agricultural and Food Chemistry, vol. 54, no. 3, pp. 732-738, 2006.

[11] C. C. Udenigwe and R. E. Aluko, "Food protein-derived bioactive peptides: production, processing, and potential health benefits," Journal of Food Science, vol. 77, no. 1, pp. R11-R24, 2012.

[12] L. Huang, B. Liu, H. Ma, and X. Zhang, "Combined effect of ultrasound and enzymatic treatments on production of ACE inhibitory peptides from wheat germ protein," Journal of Food Processing and Preservation, vol. 38, no. 4, pp. 1632-1640, 2014.

[13] H. Uluko, S. Zhang, L. Liu et al., "Pilot-scale membrane fractionation of ACE inhibitory and antioxidative peptides from ultrasound pretreated milk protein concentrate hydrolysates," Journal of Functional Foods, vol. 7, no. 1, pp. 350-361, 2014.

[14] S. U. Kadam, B. K. Tiwari, C. lvarez, and C. P. O’donnell, "Ultrasound applications for the extraction, identification and delivery of food proteins and bioactive peptides," Trends in Food Science \& Technology, vol. 46, no. 1, pp. 60-67, 2015.

[15] C. Ozuna, I. Paniagua-Martínez, E. Castaño-Tostado, L. Ozimek, and S. L. Amaya-Llano, "Innovative applications of high-intensity ultrasound in the development of functional food ingredients: Production of protein hydrolysates and bioactive peptides," Food Research International, vol. 77, pp. 685-696, 2015.

[16] J. Chandrapala, C. Oliver, S. Kentish, and M. Ashokkumar, "Ultrasonics in food processing," Ultrasonics Sonochemistry, vol. 19, no. 5, pp. 975-983, 2012.

[17] F. Dujmic, M. Brncic, S. Karlovic et al., "Ultrasound-assisted infrared drying of pear slices: Textural issues," Journal of Food Process Engineering, vol. 36, no. 3, pp. 397-406, 2013.

[18] S. U. Kadam, B. K. Tiwari, and C. P. O’Donnell, "Application of novel extraction technologies for bioactives from marine algae," Journal of Agricultural and Food Chemistry, vol. 61, no. 20, pp. 4667-4675, 2013.

[19] R. Vardanega, D. T. Santos, and M. A. De Almeida, "Intensification of bioactive compounds extraction from medicinal plants using ultrasonic irradiation," Pharmacognosy Reviews, vol. 8, no. 16, pp. 88-95, 2014.

[20] H. Feng, G. V. Barbosa-Cánovas, and J. Weiss, Ultrasound Technologies for Food and Bioprocessing, Springer Science+Business Media, LLC, 2011.

[21] L. Huang, H. Ma, L. Peng, Z. Wang, and Q. Yang, "Enzymolysis kinetics of garlic powder with single frequency countercurrent ultrasound pretreatment," Food and Bioproducts Processing, vol. 95, pp. 292-297, 2015.

[22] H. Li, J. Yu, M. Ahmedna, and I. Goktepe, "Reduction of major peanut allergens Ara h 1 and Ara h 2, in roasted peanuts by ultrasound assisted enzymatic treatment," Food Chemistry, vol. 141, no. 2, pp. 762-768, 2013.

[23] C. Zhou, H. Ma, Q. Ding et al., "Ultrasonic pretreatment of corn gluten meal proteins and neutrase: effect on protein conformation and preparation of ACE (angiotensin converting enzyme) inhibitory peptides," Food and Bioproducts Processing, vol. 91, no. 4, pp. 665-671, 2013. 
[24] C. Zhou, H. Ma, X. Yu, B. Liu, A. E.-G. A. Yagoub, and Z. Pan, "Pretreatment of defatted wheat germ proteins (byproducts of flour mill industry) using ultrasonic horn and bath reactors: Effect on structure and preparation of ACE-inhibitory peptides," Ultrasonics Sonochemistry, vol. 20, no. 6, pp. 13901400, 2013.

[25] M.-H. Morel, P. Dehlon, J. C. Autran, J. P. Leygue, and C. Barlhelgouach, "Effects of temperature, sonication time, and power settings on size distribution and extractability of total wheat flour proteins as determined by size-exclusion highperformance liquid chromatography," Cereal Chemistry, vol. 77, no. 5, pp. 685-691, 2000.

[26] J. Chandrapala, B. Zisu, M. Palmer, S. Kentish, and M. Ashokkumar, "Effects of ultrasound on the thermal and structural characteristics of proteins in reconstituted whey protein concentrate," Ultrasonics Sonochemistry, vol. 18, no. 5, pp. 951-957, 2011.

[27] A. R. Jambrak, T. J. Mason, V. Lelas, Z. Herceg, and I. L. Herceg, "Effect of ultrasound treatment on solubility and foaming properties of whey protein suspensions," Journal of Food Engineering, vol. 86, no. 2, pp. 281-287, 2008.

[28] A. Abdul-Hamid, J. Bakar, and G. H. Bee, "Nutritional quality of spray dried protein hydrolysate from Black Tilapia (Oreochromis mossambicus)," Food Chemistry, vol. 78, no. 1, pp. 6974, 2002.

[29] R. Hartmann and H. Meisel, "Food-derived peptides with biological activity: from research to food applications," Current Opinion in Biotechnology, vol. 18, no. 2, pp. 163-169, 2007.

[30] M. Paul and G. A. Somkuti, "Degradation of milk-based bioactive peptides by yogurt fermentation bacteria," Letters in Applied Microbiology, vol. 49, no. 3, pp. 345-350, 2009.

[31] S. Maruyama, E. Cantu III, C. DeMartino et al., "Interaction of baboon anti- $\alpha$-galactosyl antibody with pig tissues," The American Journal of Pathology, vol. 155, no. 5, pp. 1635-1649, 1999.

[32] J. Adler-Nissen, Enzymic Hydrolysis of Food Protein, Elsevier Applied Science Publisher, 1976.

[33] M. A. Y. Abdualrahman, H. Ma, C. Zhou, A. E. A. Yagoub, J. Hu, and X. Yang, "Thermal and single frequency counter-current ultrasound pretreatments of sodium caseinate: enzymolysis kinetics and thermodynamics, amino acids composition, molecular weight distribution and antioxidant peptides," Journal of the Science of Food and Agriculture, vol. 96, no. 15, pp. 4861-4873, 2016.

[34] A. Kato and S. Nakai, "Hydrophobicity determined by a fluorescence probe method and its correlation with surface properties of proteins.", Biochimica et Biophysica Acta, vol. 624, no. 1, pp. 13-20, 1980.

[35] S. Kentish and H. Feng, "Applications of power ultrasound in food processing," Annual Review of Food Science and Technology, vol. 5, no. 1, pp. 263-284, 2014.

[36] H. Uluko, L. Liu, H. Li et al., "Effect of power ultrasound pretreatment on peptidic profiles and angiotensin converting enzyme inhibition of milk protein concentrate hydrolysates," Journal of the Science of Food and Agriculture, vol. 94, no. 12, pp. 2420-2428, 2014.

[37] B. Wang, G. G. Atungulu, R. Khir et al., "Ultrasonic Treatment Effect on Enzymolysis Kinetics and Activities of ACEInhibitory Peptides from Oat-Isolated Protein," Food Biophysics, vol. 10, no. 3, pp. 244-252, 2015.

[38] B. Wang, T. Meng, H. Ma et al., "Mechanism study of dualfrequency ultrasound assisted enzymolysis on rapeseed protein by immobilized Alcalase," Ultrasonics Sonochemistry, vol. 32, pp. 307-313, 2016.

[39] H. Uluko, H. Li, W. Cui et al., "Response surface optimization of angiotensin converting enzyme inhibition of milk protein concentrate hydrolysates in vitro after ultrasound pretreatment," Innovative Food Science and Emerging Technologies, vol. 20, pp. 133-139, 2013.

[40] J. Jia, H. Ma, W. Zhao et al., "The use of ultrasound for enzymatic preparation of ACE-inhibitory peptides from wheat germ protein," Food Chemistry, vol. 119, no. 1, pp. 336-342, 2010.

[41] W. Qu, H. Ma, J. Jia, R. He, L. Luo, and Z. Pan, "Enzymolysis kinetics and activities of ACE inhibitory peptides from wheat germ protein prepared with SFP ultrasound-assisted processing," Ultrasonics Sonochemistry, vol. 19, no. 5, pp. 1021-1026, 2012.

[42] J. Jiang, S. Chen, F. Ren, Z. Luo, and S. S. Zeng, "Yak milk casein as a functional ingredient: Preparation and identification of angiotensin-I-converting enzyme inhibitory peptides," Journal of Dairy Research, vol. 74, no. 1, pp. 18-25, 2007.

[43] H. G. Akillioğlu and S. Karakaya, "Effects of heat treatment and in vitro digestion on the angiotensin converting enzyme inhibitory activity of some legume species," European Food Research and Technology, vol. 229, no. 6, pp. 915-921, 2009.

[44] A. Quirós, R. Chichón, I. Recio, and R. López-Fandiño, “The use of high hydrostatic pressure to promote the proteolysis and release of bioactive peptides from ovalbumin," Food Chemistry, vol. 104, no. 4, pp. 1734-1739, 2007.

[45] B. Lei, K. Majumder, S. Shen, and J. Wu, "Effect of sonication on thermolysin hydrolysis of ovotransferrin," Food Chemistry, vol. 124, no. 3, pp. 808-815, 2011.

[46] S. Li, X. Yang, Y. Zhang et al., "Effects of ultrasound and ultrasound assisted alkaline pretreatments on the enzymolysis and structural characteristics of rice protein," Ultrasonics Sonochemistry, vol. 31, pp. 20-28, 2016.

[47] E. Lourenço da Costa, J. Antonio da Rocha Gontijo, and F. M. Netto, "Effect of heat and enzymatic treatment on the antihypertensive activity of whey protein hydrolysates," International Dairy Journal, vol. 17, no. 6, pp. 632-640, 2007.

[48] G.-H. Li, G.-W. Le, Y.-H. Shi, and S. Shrestha, "Angiotensin Iconverting enzyme inhibitory peptides derived from food proteins and their physiological and pharmacological effects," Nutrition Research, vol. 24, no. 7, pp. 469-486, 2004.

[49] S. Mizuno, S. Nishimura, K. Matsuura, T. Gotou, and N. Yamamoto, "Release of short and proline-rich antihypertensive peptides from casein hydrolysate with an Aspergillus oryzae protease," Journal of Dairy Science, vol. 87, no. 10, pp. 3183-3188, 2004.

[50] X.-S. Wang, C.-H. Tang, B.-S. Li, X.-Q. Yang, L. Li, and C.-Y. Ma, "Effects of high-pressure treatment on some physicochemical and functional properties of soy protein isolates," Food Hydrocolloids, vol. 22, no. 4, pp. 560-567, 2008.

[51] I. Gülseren, D. Güzey, B. D. Bruce, and J. Weiss, "Structural and functional changes in ultrasonicated bovine serum albumin solutions," Ultrasonics Sonochemistry, vol. 14, no. 2, pp. 173-183, 2007.

[52] L. Jiang, J. Wang, Y. Li et al., "Effects of ultrasound on the structure and physical properties of black bean protein isolates," Food Research International, vol. 62, pp. 595-601, 2014.

[53] Y. Sun, J. Chen, S. Zhang et al., "Effect of power ultrasound pretreatment on the physical and functional properties of reconstituted milk protein concentrate," Journal of Food Engineering, vol. 124, pp. 11-18, 2014. 
[54] C. Arzeni, K. Martínez, P. Zema, A. Arias, O. E. Pérez, and A. M. R. Pilosof, "Comparative study of high intensity ultrasound effects on food proteins functionality," Journal of Food Engineering, vol. 108, no. 3, pp. 463-472, 2012.

[55] D. W. Cushman and H. S. Cheung, "Spectrophotometric assay and properties of the angiotensin-converting enzyme of rabbit lung," Biochemical Pharmacology, vol. 20, no. 7, pp. 1637-1648, 1971.

[56] Z. Zhang, J. M. Regenstein, P. Zhou, and Y. Yang, "Effects of high intensity ultrasound modification on physicochemical property and water in myofibrillar protein gel," Ultrasonics Sonochemistry, vol. 34, pp. 960-967, 2017.

[57] D. H. G. Pelegrine and C. A. Gasparetto, "Whey proteins solubility as function of temperature and $\mathrm{pH}$," LWT- Food Science and Technology, vol. 38, no. 1, pp. 77-80, 2005.

[58] C.-H. Tang, X.-Y. Wang, X.-Q. Yang, and L. Li, "Formation of soluble aggregates from insoluble commercial soy protein isolate by means of ultrasonic treatment and their gelling properties," Journal of Food Engineering, vol. 92, no. 4, pp. 432437, 2009.

[59] A. R. Jambrak, T. J. Mason, V. Lelas, and G. Krešić, "Ultrasonic effect on physicochemical and functional properties of $\alpha$ lactalbumin," LWT- Food Science and Technology, vol. 43, no. 2, pp. 254-262, 2010.

[60] J.-M. Chobert, M. Z. Sitohy, and J. R. Whitaker, "Solubility and emulsifying properties of caseins modified enzymatically by staphylococcus aureus v8 protease," Journal of Agricultural and Food Chemistry, vol. 36, no. 1, pp. 220-224, 1988.

[61] I. P. Claver and H. Zhou, "Enzymatic hydrolysis of defatted wheat germ by proteases and the effect on the functional properties of resulting protein hydrolysates," Journal of Food Biochemistry, vol. 29, no. 1, pp. 13-26, 2005.

[62] I.-C. Sheih, T. J. Fang, and T.-K. Wu, "Isolation and characterisation of a novel angiotensin I-converting enzyme (ACE) inhibitory peptide from the algae protein waste," Food Chemistry, vol. 115, no. 1, pp. 279-284, 2009.

[63] C.-Z. Zhu, W.-G. Zhang, Z.-L. Kang, G.-H. Zhou, and X.-L. Xu, "Stability of an antioxidant peptide extracted from Jinhua ham," Meat Science, vol. 96, no. 1, pp. 783-789, 2014.

[64] J. I. Boye, C.-Y. Ma, A. Ismail, V. R. Harwalkar, and M. Kalab, "Molecular and Microstructural Studies of Thermal Denaturation and Gelation of $\beta$-Lactoglobulins A and B," Journal of Agricultural and Food Chemistry, vol. 45, no. 5, pp. 1608-1618, 1997.

[65] H. Korhonen, A. Pihlanto-Leppälä, P. Rantamäki, and T. Tupasela, "Impact of processing on bioactive proteins and peptides," Trends in Food Science \& Technology, vol. 9, no. 8-9, pp. 307-319, 1998.

[66] J.-S. Hwang, "Impact of processing on stability of angiotensin Iconverting enzyme (ACE) inhibitory peptides obtained from tuna cooking juice," Food Research International, vol. 43, no. 3, pp. 902-906, 2010.

[67] W. Wu, P.-P. Yu, F.-Y. Zhang, H.-X. Che, and Z.-M. Jiang, "Stability and cytotoxicity of angiotensin-I-converting enzyme inhibitory peptides derived from bovine casein," Journal of Zhejiang University SCIENCE B, vol. 15, no. 2, pp. 143-152, 2014.

[68] R. López-Fandiño, J. Otte, and J. van Camp, "Physiological, chemical and technological aspects of milk-protein-derived peptides with antihypertensive and ACE-inhibitory activity," International Dairy Journal, vol. 16, no. 11, pp. 1277-1293, 2006.
[69] E. Escudero, L. Mora, and F. Toldrá, "Stability of ACE inhibitory ham peptides against heat treatment and in vitro digestion," Food Chemistry, vol. 161, pp. 305-311, 2014. 

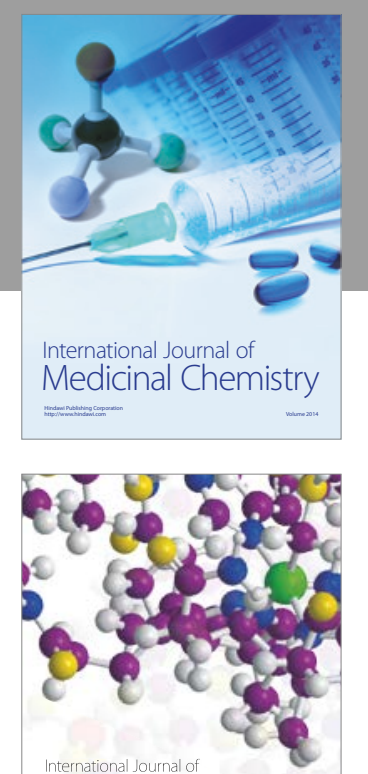

Carbohydrate Chemistry

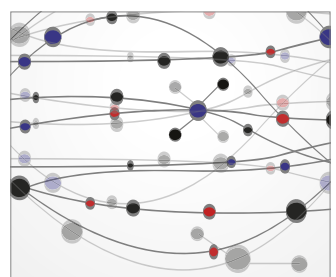

The Scientific World Journal
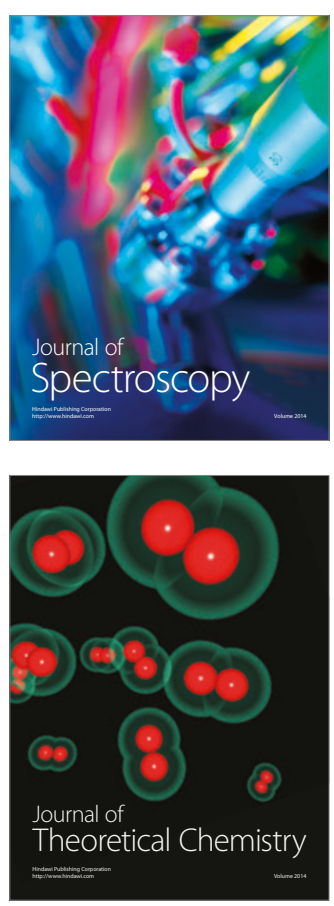
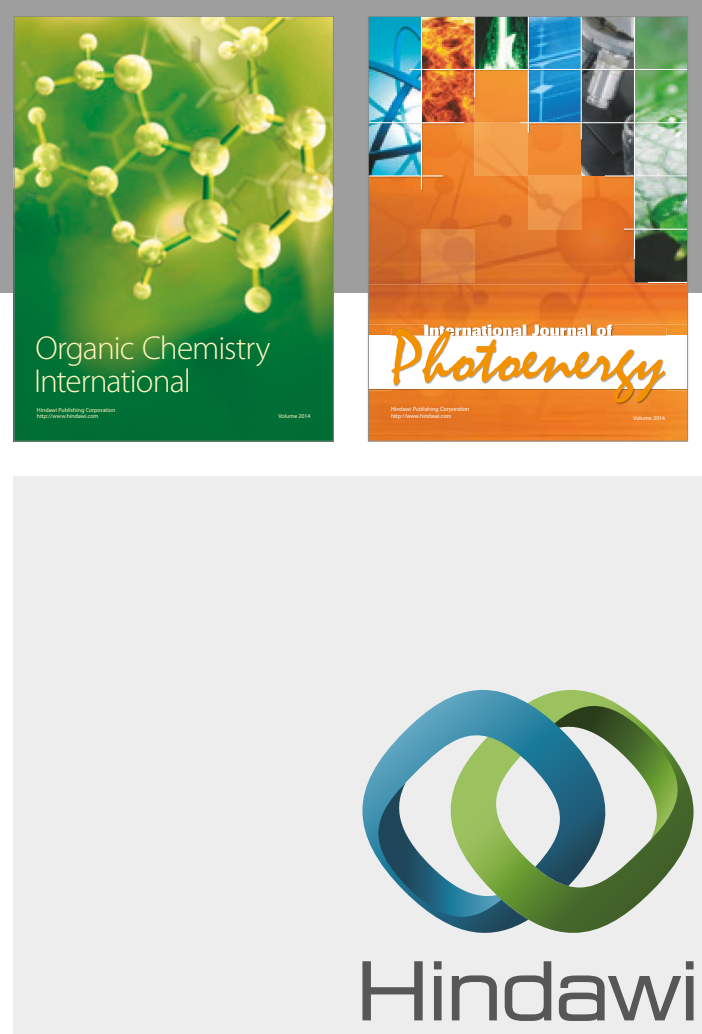

Submit your manuscripts at

https://www.hindawi.com

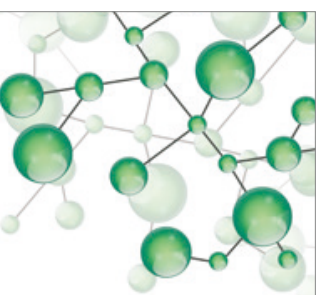

International Journal of

Inorganic Chemistry

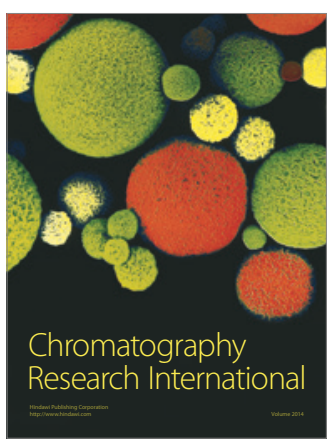

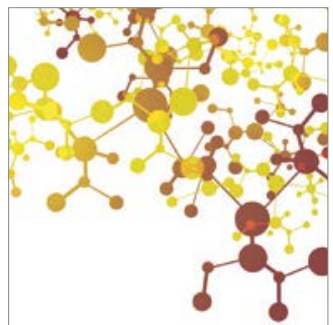

Applied Chemistry
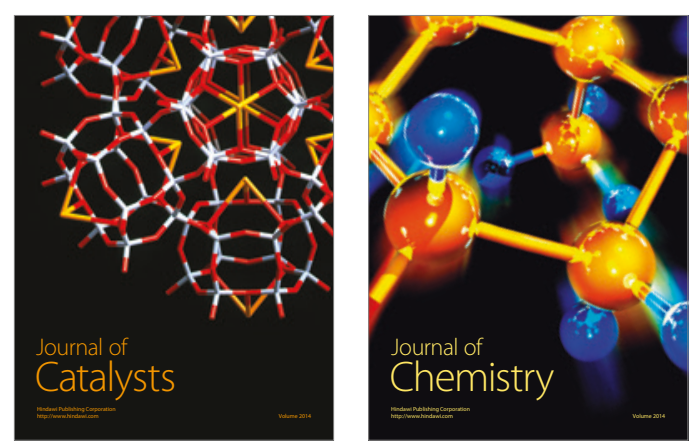
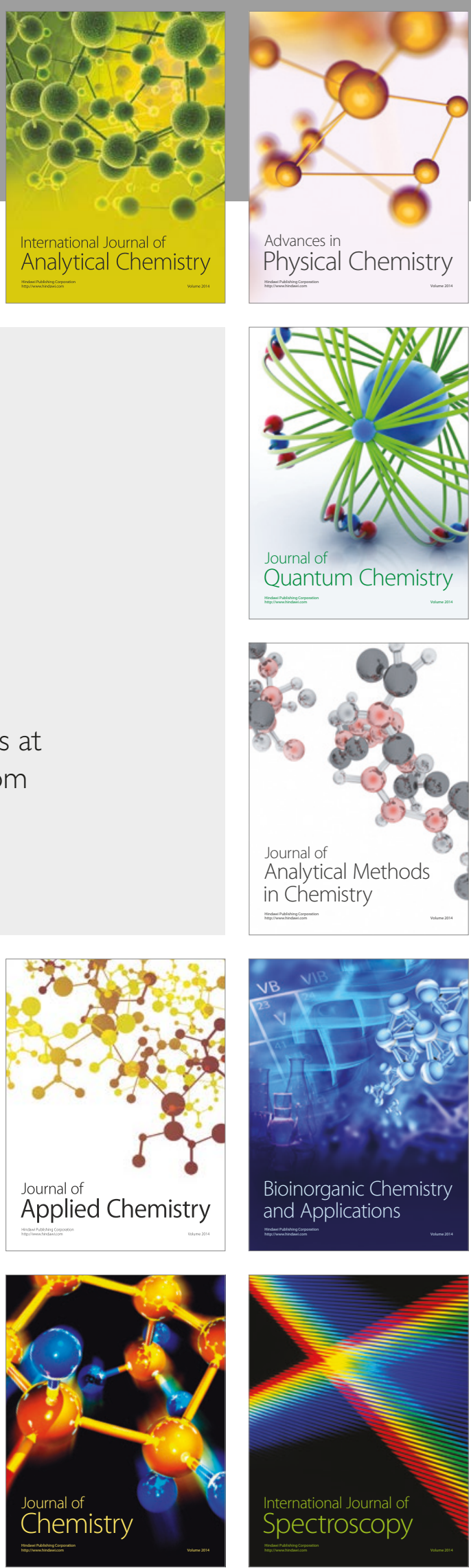